В заключение хотим отметить, что работа, которая проводится в рамках реализации программы этнокультурного казачьего образования в Амурской области это значимый и кропотливый труд, требующий самоотдачи, так как направлен на формирование образовательного пространства для воспитания личности патриота России на основе исторически сложившихся традиций и обычаев амурского казачества.

$$
* * *
$$

1. Вакуленко О.Б., Казакова Е.Н. Реализация казачьего компонента в начальной школе. Справочнометодические материалы. - Благовещенск, 2018, с. 210.

2. Вакуленко О.Б. Методические рекомендации педагогам образовательных организаций по реализации казачьего образовательного компонента. - Благовещенск, 2017, с. 56.

3. Закон Амурской области «О развитии российского казачества на территории Амурской области» № 543-О3 от 07.05.2015.

4. Закон «Об образовании в Российской Федерации» №273-Ф3 от 29.12.2012.

5. Казакова Е.Н. Программа учебного курса для обучающихся 5-11 классов «История казачества» и инструментарий по мониторингу готовности и достаточности условий, созданных в школах области, к реализации казачьего образовательного компонента в рамках образовательной программы. - Благовещенск, 2017, с. 78.

6. Концепция государственной политики Российской Федерации в отношении казачества, утвержденная Распоряжением Президента Российской Федерации от 02.07.2008 № Пр-1355.

7. Приказ министерства образования и науки Амурской области «О введении в рамках образовательной программы общеобразовательных организаций Амурской области казачьего образовательного компонента» № 1186 от 02 сентября 2016 года.

8. Приказ Минпросвещения России «Об утверждении Порядка организации и осуществления образовательной деятельности по дополнительным общеобразовательным программам» №196 от 09.11.2018.

9. Распоряжение Правительства Амурской области от 22 февраля 2019 г. № 29-р «Об утв. плана мероприятий по реализации на территории Амур. обл. в 2019-2020 гг. «Стратегии развития Государственной политики РФ в отношении российского казачества до 2020 г.»

10. «Стратегия развития государственной политики Российской Федерации в отношении российского казачества до 2020 года», утверждена Президентом РФ 15.09.2012 № Пр-2789.

\title{
Виноградова М.Т., Медведева И.А. \\ Эстетическое отношение к музыке и его психологические основы в младшем школьном возрасте
}

Чувашский государственный педагогический институт им. И. Я. Яковлева (Россия, Чебоксары)

doi: $10.18411 / \mathrm{j}-06-2021-157$

\section{Аннотация}

В статье раскрываются механизмы формирования и развития эстетического отношения учащихся к окружающему миру. С опорой на психологические особенности младшего школьного возраста определены структура эстетической оценочной деятельности детей и факторы, способствующие ее развитию. На примере музыкальной деятельности раскрыты основные подходы к организации процесса формирования у младших школьников эстетического отношения к музыке.

Ключевые слова: эстетическое отношение, эмоционально-эстетический опыт, психологические особенности, младшие школьники, эстетическая оценка.

\section{Abstract}

The article reveals the mechanisms of formation and development of the aesthetic attitude of students to the surrounding world. Based on the psychological characteristics of primary school age, the structure of the aesthetic evaluation activity of children and the factors contributing to its development are determined. On the example of musical activity, 
the main approaches to the organization of the process of forming an aesthetic attitude to music in younger schoolchildren are revealed.

Keywords: aesthetic attitude, emotional and aesthetic experience, psychological characteristics, primary school students, aesthetic assessment.

Проблема формирования эстетического отношения не нова, она привлекает внимание ученых разных отраслей знания. Традиционно ее изучают философы, педагоги и психологи, раскрывающие отличительные черты эстетического отношения и его психологический фундамент. Общим во взглядах исследователей является то, что эстетическое отношение понимается как результат чувственного восприятия и анализа, находящий свое выражение в эстетической оценке и суждении. Так, М. С. Каган указывал, что в эстетическом отношении человека только непосредственное переживание, его сила и направленность испытанного чувства являются достаточным основанием для возникновения оценочного суждения. И это более глубокое погружение в отношения с окружающим миром, нежели, например, познавательное отношение, поскольку задействована сугубо личностная - эмоционально-чувственная сфера человека.

Подчеркивая значительную роль переживания, заметим, что одной из форм выражения эстетического отношения личности является эстетическая оценка, которой подвергаются только те свойства и стороны конкретного явления, что доступны непосредственному чувственному восприятию и переживанию. В отличие от утилитарной, этической и других видов оценки, которые не требуют непременного включения оцениваемого явления в жизненный опыт человека, в эстетическом отношении это необходимо, так как то, что не воспринято «лично», не имеет никакой эстетической ценности для личности.

Справедливо замечено, что эстетическое отношение имеет одновременно чувственно-практический и теоретико-познавательный характер. Иначе говоря, оно субъективно в силу того, что отражает личный опыт воспринимающего и содержит определенное соотношение эмоционального и рационального в восприятии мира. Что касается теоретико-познавательного характера эстетического отношения, то оно всегда формируется на основе оперативных мыслительных операций (анализ, сопоставление, обобщение и др.).

Для педагога-музыканта важны обе эти стороны, поскольку на этапе первоначального восприятия музыки ребенок, как правило, опирается на эмоциональную реакцию (нравится - не нравится), до конца не осознавая, почему и откуда возникает именно такая реакция. Это вполне закономерно, потому что, как доказал В. Г. Ражников, в эстетическом переживании человек всегда воспроизводит дифференцированные энергии, закодированные в произведении искусства [1]. Более того, в содержательную сторону музыки включены генетически более молодые эмоции, порожденные искусством и породившие искусство.

В учащихся они проявляются в момент, когда они действуют как «художник», поэтому эстетические эмоции всегда имеют личностное накопление. Так, например, восприятие музыкального произведения включает в себя познавательные, эмоциональные и эмоционально-оценочные процессы. Общение ребенка с музыкой начинается с распознавания использованных в произведении языковых элементов (музыкального языка), соответствующих им содержательных и коммуникативных значений. С узнаванием тесно связаны слуховые коррекции и домысливание отсутствующих признаков в соответствии с накопленным учащимися опыта восприятия музыки. Распознавая эмоции, связанные с художественным содержанием, учащиеся проникаются ими и воспринимают уже как собственные переживания. При 
этом эмоционально-оценочные реакции могут быть положительными или отрицательными, в зависимости от того, насколько произведение отвечает желаниям и потребностям учащихся.

Общеизвестен и тот факт, что в формировании эстетического отношения участвует также мышление. Так, осмысление звуков и их взаимосвязи, определяющих структуру произведения, происходит на уровне ситуативного, ассоциативного мышления. Эстетическое восприятие является исключительно обобщенным и ассоциативным, так форма музыкального произведения всегда что-то выражает и ассоциируется с определенным содержанием. А поскольку звуковых ассоциаций может возникать великое множество, элементы формы выступают в восприятии как обобщенные признаки, которые способствуют более глубокому освоению произведения, накоплению человеком чувственного опыта и дают возможность применить его в постижении других произведений.

Бесспорным является также и то, что в основе эстетического отношения субъекта всегда лежат оценочные нормы, формирование которых в индивидуальном сознании осуществляется в ходе онтогенеза, а в общественном - в ходе филогенеза. Так, многократное повторение восприятия объектов и выделение в них общих признаков приводит, в конце концов, к созданию некоего обобщенного образа с характерными свойствами, который в дальнейшем используется как оценочная норма. А поскольку обобщения осуществляются в основном на эмпирическом уровне, то отдельные освоенные человеком признаки совершенства и несовершенства абстрагируются и закрепляются за образами явлений, для которых они наиболее характерны. Тогда эстетический критерий уже выступает в форме символа - образапонятия. В ходе накопления эстетического опыта учащиеся неосознанно закрепляют за определенными звучаниями какие-то эстетические признаки, которые впоследствии распространяются на подобные звуковые сочетания. Можно говорить о том, что в онтогенезе в сжатой форме представлен процесс отбора и обобщений, осуществляемых в филогенезе.

Многие связи, ассоциации, освоенные человеком, становятся привычными, а целесообразность отобранных признаков многократно проверена в личном и коллективном опыте, поэтому они часто не осознаются нами в полной мере, например, значение средств музыкальной выразительности в организации музыкальнопоэтического произведения. Таким образом, формирование эстетического отношения представляет собой сложный психологический процесс, требующий учета особенностей воспринимающего субъекта, в данном случае - детей младшего школьного возраста.

Следует понимать, какие факторы способствуют формированию эстетического отношения в данном возрасте. Сошлемся на исследование Н. А. Терентьевой, в котором представлены субъективные (личностные) факторы. $\mathrm{K}$ таковым относятся: художественный тип личности школьника (явно выраженная связь первой и второй сигнальной системы); высокая чувствительность сенсорных зон нервной системы; сензитивность младшего школьного возраста; синкретизм задатков различных художественных способностей (повышенный интерес и склонность детей к различным видам художественной деятельности); эмоциональная впечатлительность младших школьников [2].

Остановимся на некоторых из них. Так, высокая чувствительность сенсорных зон нервной системы в данном возрасте позволяет им активно обогащать свои зрительные, слуховые, обонятельные и особенно речеслуховые представления, что является основой образной памяти, образного мышления, богатого и сильного воображения и ассоциаций. Особую восприимчивость младших школьников к 
различным видам искусства следует рассматривать как возрастную предпосылку для формирования эстетического отношения и эстетической оценки. Если в этом возрасте ребенок не будет получать в достаточном количестве художественных впечатлений, если не будут созданы условия для закрепления и упорядочения комплекса тех свойств личности, благодаря которым обеспечивается его взаимодействие с искусством и действительностью, то в зрелом возрасте он уже не сможет наверстать упущенное. Например, педагогами замечено, что если слушание музыки с детьми не было должным образом организовано до 9-10 лет, то с трудом восполняется потом вплоть до юношеского возраста и в дальнейшем препятствует восприятию интонационного богатства поэтической речи.

Нельзя не отметить и повышенный интерес младших школьников к различным видам художественной деятельности; они с увлечением рисуют, сочиняют сказки, поют, принимают участие в театрализованных представлениях и т.п. В процессе такой деятельности у учащихся формируется эстетическое отношение и к самой деятельности, и к отдельным произведениям искусства. И это не случайно, поскольку психологи давно установили, что непосредственным фактором развития ребенка является его собственная деятельность. Следовательно, исходным принципом в формировании эстетического отношения и оценки должна стать та эстетическая активность, которую проявляют младшие школьники на музыкальных занятиях.

В таком случае можно обозначить подходы к реализации данного процесса, которые, в свою очередь, могут стать основой методики музыкального обучения. Вопервых, очевидно, эмоционально-эстетический и слуховой опыт обучающихся должен быть в приоритете по отношению к технологии обучения. Во-вторых, универсальность эстетической эмоции позволяет формировать ее сразу на нескольких видах искусства, например, музыка, поэзия, живопись, театрализация и др. В-третьих, эмоция может быть освоена в простейших формах художественной деятельности (так называемая прахудожественная деятельность), которая доступна любому начинающему: спонтанная ритмическая импровизация, абстрактные цветовые композиции и др. Кроме того, здесь важен избранный способ действий - импровизация, потому как она задается на определенное настроение или эмоцию, а создается с помощью звуков, цветов, ритма и т.д. Наконец, после освоения всех элементов эмоционально-эстетического восприятия осуществляется переход от спонтанной художественной деятельности непосредственно в музыкально-предметный мир с богатым набором средств выразительности и понятийным аппаратом.

Целесообразность такого алгоритма заключается в том, что он подчеркивает непременное условие успешного процесса обучения - обоюдное развитие учащегося и педагога, нацеливает и педагогов и родителей на возможность более раннего накопления детьми эмоционально-эстетического опыта в различных видах деятельности. Конечной целью такого развития является умение школьниками адекватно воспринять и сформировать свое эстетическое отношение к музыке в совокупности формы и содержания конкретного произведения. Педагогическое же сопровождение призвано направлять данный процесс и обеспечивать его эффективность.

1. Ражников В. Г. Диалоги о музыкальной педагогике. М. : Музыка, 1989. - 148 с.

2. Терентьева, Наталия Алексеевна Художественно-творческое развитие младших школьников на уроках музыки в процессе целостного восприятия различных видов искусства / Н. А. Терентьева; М-во нар. образования РСФСР. - М. : Прометей, 1990. - 184 с. 